
\title{
is Research Square \\ The Antidiabetic and Spectral Analysis of Various Extracts of Lilium Polyphyllum
}

mohd mir ( $\square$ mohdaminmir@gmail.com )

Prince Mohammad Bin Fahd University https://orcid.org/0000-0003-4689-0507

waqar ashraf

Prince Mohammad Bin Fahd University

priya singh

Council of Scientific \& Industrial Research Indian Institute of Integrative Medicine

\section{Research}

Keywords: Antidiabetic, Lilium polyphyllum, Palmitic acid, Piperine, amylase, glycosidase

Posted Date: July 17th, 2020

DOl: https://doi.org/10.21203/rs.3.rs-42363/v1

License: (c) (i) This work is licensed under a Creative Commons Attribution 4.0 International License.

Read Full License 


\section{The Antidiabetic and Spectral Analysis of Various Extracts of Lilium polyphyllum}

\section{Amin Mir', Muhammad Waqar Ashraf ${ }^{2}$, Priya Singh $^{3}$}

1. Assistant Research Professor, Department of Mathematics \& Natural Sciences, Prince Mohammad Bin Fahd University, AlKhobar, Saudi Arabia

2. Dean Department of Mathematics \& Natural Sciences, Prince Mohammad Bin Fahd University, AlKhobar, Saudi Arabia

3. Research Scholar, IIIM Jammu.

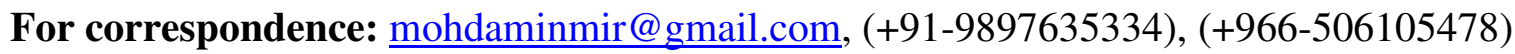

Abstract

Background: The Antidiabetic and Spectral Analysis of Various Extracts of Lilium polyphyllum Methods: The study involves antidiabetic and spectral analysis, in which inhibition of alpha amylase and alpha glycosidase inhibition was carried out by various extracts of Lilium polyphyllum.

Results: The plant showed a good inhibiting potential of amylase and glycosidase, the two key enzymes responsible for the breakdown of oligosaccharides into glucose molecules. Among the extracts the inhibition of alpha amylase was found to be $54.95 \%$ by water extract, $53.01 \%$ by ethanol extract and $47.87 \%$ by DCM extract. The percentage inhibition of alpha glucosidase was found to be $48.48 \%$ by water extract, $48.48 \%$ by ethanol extract and $43.85 \%$ by DCM extracts. GC-MS analysis involves isolation of, Methyl 2-furoate, 5-hydroxymethyl furfural, Methyl piperate, Piperine, Palmitic acid, Methyl Palmitate, which in turn justifies the antidiabetic properties of the concerned plant. So the plant can act as good source of antidiabetic drug. The water extract is more beneficial than other extracts.

Conclusion: The inhibiting potential of natural products have been found as a good choice for the diabetic patients as they did not led to side effects. Similarly in the above study it had been found that Lilium polyphyllum posses many biosignitures which have the amylase and glycosidase inhibiting potential, among which polar components have more tendency than the less polar.

Keywords: Antidiabetic, Lilium polyphyllum, Palmitic acid, Piperine, amylase, glycosidase Background

Ayurveda is the essential and the eternal science of life (Pandeya G et.al, 2011) as being associated with the noble, excellent and great tradition. The main purpose of Ayurveda is to protect the person and to keep the fitness of a healthy person and to mitigate the disorders of a patient (Sharma, Singh. et.al, 2017) which else may have fetal out comings. Nearly $80 \%$ of the 
population of developing countries is directly dependent on traditional medicines, which they consume from plants, for their primary health care needs.

Lilium polyphyllum commonly known as Kshirkakoli or white lilly (family Liliaceae) is extensively used in many indigenous preparations from times immoral. Kshirkakoli have been found to contain Sugar, Alkaloids, flavanoids, and essential Steroids (Subramoniam et.al 2013). Medicinally, the bulb of this species is used as diuretic, antipyretic and as a energy tonic (Ayurvedic Pharmacopoeia of India. 2001, Dhyani A, 2009, Dhyani A, 2010, Kumari S, 2011). Few species of the plant are also known for medicinal and food value (Chang C, 2000, Wawrosch C, 2001), which increased its economic importance many folds.

In traditional system of medicine, the species reported to restore health immediately and works as antioxidant in the body (Sharma BD, 2005).

Diabetes is considered as one of the fetal causes of death worldwide as per the estimation in every ten second a person dies from diabetes related problems. In 2007, it was reported by (Das AK et al 2008) that diabetes caused 3.5 million deaths globally. Diabetes was considered as 'a disease of rich man' but now it had spread among all masses (Gupta R et al 2007) in India as well in the whole world. Mostly developing countries have large number of diabetic patients but India is considered as infamously dubbed 'diabetic capital of the world' (Abate $N$ et al 2007) because of the largest number of diabetic patients.

\section{Materials and Methods}

\section{Plant materials}

The plant material was collected from Kishtwar region of Jammu and Kashmir and was authenticated at FRI Dehradun. The collection process was preferably done in the dry condition. Plant was shade dried at room temperature and the plant samples were air dried and grounded into uniform powder with a grinder.

\section{Materials and Methods}

All the chemicals used in this investigation were of analytical reagent (AR) grade and were purchased from Sigma Merck. De-ionized water was used in the whole study. All the glassware and equipment used for handling were stabilized properly prior to use. 


\section{Extraction}

The extraction procedure was carried out first with DCM followed by ethanol and then with water based upon their polarity index. The extraction was done by Soxhlet extraction using thimble to get the pure form of extract. $75 \mathrm{~g}$ of the plant material was used for extraction.

In vitro methods employed in antidiabetic studies (Hamdan, Afifi FU, 2004)

\section{Inhibition of alpha amylase enzyme}

A total of $500 \mu \mathrm{L}$ of test samples and standard drug $(100-1000 \mu \mathrm{g} / \mathrm{ml})$ were added to 500 $\mu \mathrm{l}$ of $0.20 \mathrm{mM}$ phosphate buffer $(\mathrm{pH} 6.9)$ containing $\alpha$-amylase $(0.5 \mathrm{mg} / \mathrm{ml})$ solution and were incubated at $25^{\circ} \mathrm{C}$ for $10 \mathrm{~min}$. After these, $500 \mu \mathrm{L}$ of a $1 \%$ starch solution in $0.02 \mathrm{M}$ sodium phosphate buffer ( $\mathrm{pH}$ 6.9) was added to each tube. The reaction mixtures were then incubated at $25^{\circ} \mathrm{C}$ for $10 \mathrm{~min}$. The reaction was stopped with $1.0 \mathrm{ml}$ of 3,5 di-nitro salicylic acid colour reagent. The test tubes were then incubated in a boiling water bath for $5 \mathrm{~min}$, cooled to room temperature. The reaction mixture was then diluted after adding $10 \mathrm{ml}$ distilled water and absorbance was measured at $540 \mathrm{~nm}$. Control represent 100\% enzyme activity and were conducted in similar way by replacing extract with vehicle (Thalapaneni NR, 2008. Heidari R, 2005).

\section{Inhibition of alpha-glycosidase enzyme}

The inhibitory activity was determined by incubating a solution of starch substrate $(2 \% \mathrm{w} / \mathrm{v}$ maltose or sucrose) $1 \mathrm{ml}$ with $0.2 \mathrm{M}$ Tris buffer $\mathrm{pH} 8.0$ and various concentration of plant extract for $5 \mathrm{~min}$ at $37^{\circ} \mathrm{C}$. The reaction was initiated by adding $1 \mathrm{ml}$ of alpha-glucosidase enzyme $(1 \mathrm{U} / \mathrm{ml})$ to it followed by incubation for $40 \mathrm{~min}$ at $35^{\circ} \mathrm{C}$. Then the reaction was terminated by the addition of $2 \mathrm{ml}$ of $6 \mathrm{~N} \mathrm{HCl}$. Then the intensity of the colour was measured at 540nm (Krishnaveni, S, 1984).

\section{Calculation of $50 \%$ Inhibitory Concentration (IC50)}

The concentration of the plant extracts required to scavenge $50 \%$ of the radicals (IC50) was calculated by using the percentage scavenging activities at five different concentrations of the extract. Percentage inhibition (I \%) was calculated by

$$
\mathbf{I} \%=(\text { Ac-As }) / A c \text { X } 100 \quad \text { (Shai L, 2010) }
$$


Where $A c$ is the absorbance of the control and $A s$ is the absorbance of the sample.

\section{Observations and Results}

In the study the Acarbose has been used as a standard drug for the inhibition of amylases and glucosidases, and it had been found that the inhibition of the concerned enzymes occur very well in which the maximum inhibition was shown by water extract followed by ethanol and least results were observed for the DCM extracts. The results are shown in the respective tables and a comparative study could be observed from the figures.

Table 1: Data of ACAROSE Standard Drug for Amylase Enzyme

\begin{tabular}{|c|c|c|c|}
\hline S. No & $\begin{array}{l}\text { Conc. of Sample } \\
(\mu \mathrm{g} / \mathrm{ml})\end{array}$ & $\begin{array}{l}\% \text { of } \\
\text { Inhibition }\end{array}$ & $\mathrm{IC}_{50}$ \\
\hline 1 & 5 & 16.1 & \multirow{10}{*}{15.55} \\
\hline 2 & 10 & 32.02 & \\
\hline 3 & 15 & 49.12 & \\
\hline 4 & 20 & 65.51 & \\
\hline 5 & 25 & 82.73 & \\
\hline 6 & 30 & 99.95 & \\
\hline 7 & 35 & 117.12 & \\
\hline 8 & 40 & 134.23 & \\
\hline 9 & 45 & 152.11 & \\
\hline 10 & 50 & 169.12 & \\
\hline
\end{tabular}

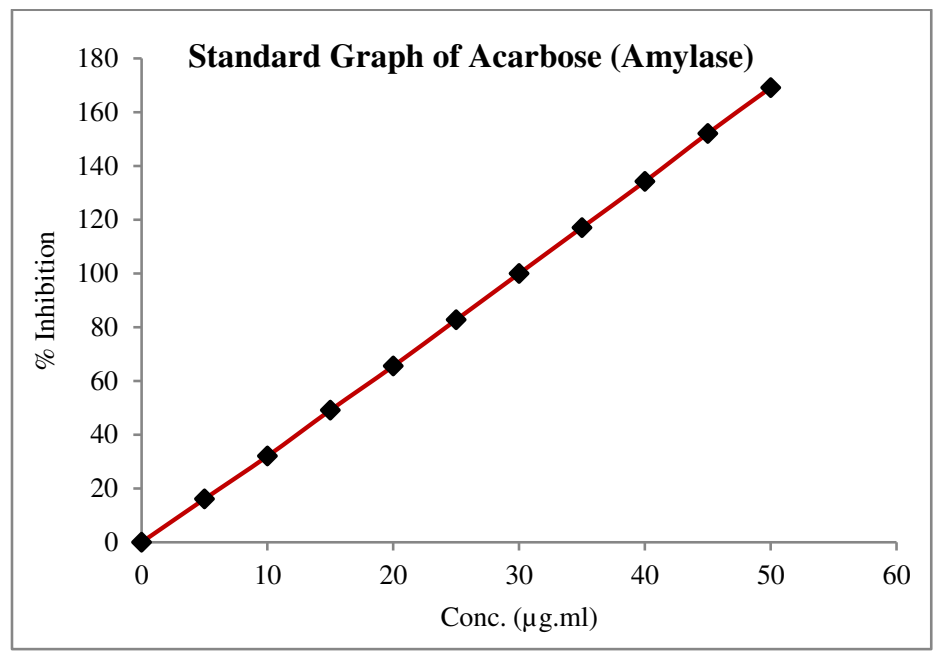

Fig 1: Graph showing inhibition of alpha-amylase by ACAROSE Standard Drug

Table 2: Data of Water Extract for Amylase Enzyme inhibition

\begin{tabular}{|c|c|c|c|}
\hline S. No & $\begin{array}{l}\text { Conc. of Sample } \\
(\mu \mathrm{g} / \mathrm{ml})\end{array}$ & $\begin{array}{c}\% \text { of } \\
\text { Inhibition }\end{array}$ & $\mathbf{I C}_{50}$ \\
\hline 1 & 20 & 27.9 & \multirow{5}{*}{45.05} \\
\hline 2 & 40 & 48.8 & \\
\hline 3 & 60 & 62.3 & \\
\hline 4 & 80 & 87.5 & \\
\hline 5 & 100 & 96.4 & \\
\hline
\end{tabular}

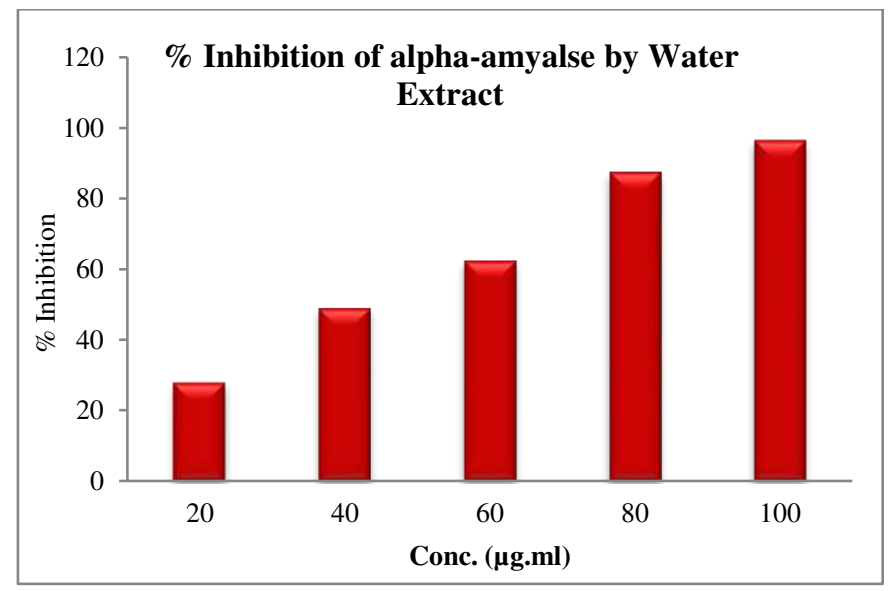

Fig 2: Graph showing inhibition of alpha-amylase by Water Extract

Table 3: Data of Ethanol Extract for Amylase Enzyme inhibition 


\begin{tabular}{|c|c|c|c|}
\hline S. No & $\begin{array}{l}\text { Conc. of Sample } \\
(\mu \mathrm{g} / \mathrm{ml})\end{array}$ & $\begin{array}{c}\% \text { of } \\
\text { Inhibition }\end{array}$ & $\mathrm{IC}_{50}$ \\
\hline 1 & 20 & 32.71 & \multirow{5}{*}{47.00} \\
\hline 2 & 40 & 45.91 & \\
\hline 3 & 60 & 57.21 & \\
\hline 4 & 80 & 71.51 & \\
\hline 5 & 100 & 89.14 & \\
\hline
\end{tabular}

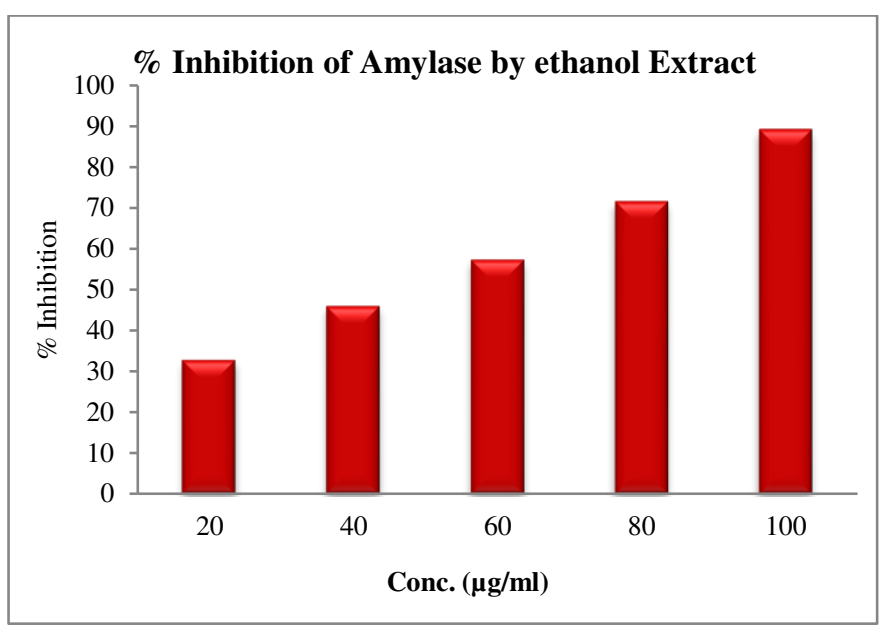

Fig 3: Graph showing inhibition of alpha-amylase by Ethanolic Extract

Table 4: Data of DCM Extract for Amylase Enzyme inhibition

\begin{tabular}{|c|c|c|c|}
\hline S. No & $\begin{array}{l}\text { Conc. of Sample } \\
(\mu \mathrm{g} / \mathrm{ml})\end{array}$ & $\begin{array}{c}\% \text { of } \\
\text { Inhibition }\end{array}$ & $\mathrm{IC}_{50}$ \\
\hline 1 & 20 & 20.1 & \multirow{5}{*}{52.12} \\
\hline 2 & 40 & 40.2 & \\
\hline 3 & 60 & 55.9 & \\
\hline 4 & 80 & 71.3 & \\
\hline 5 & 100 & 79.5 & \\
\hline
\end{tabular}

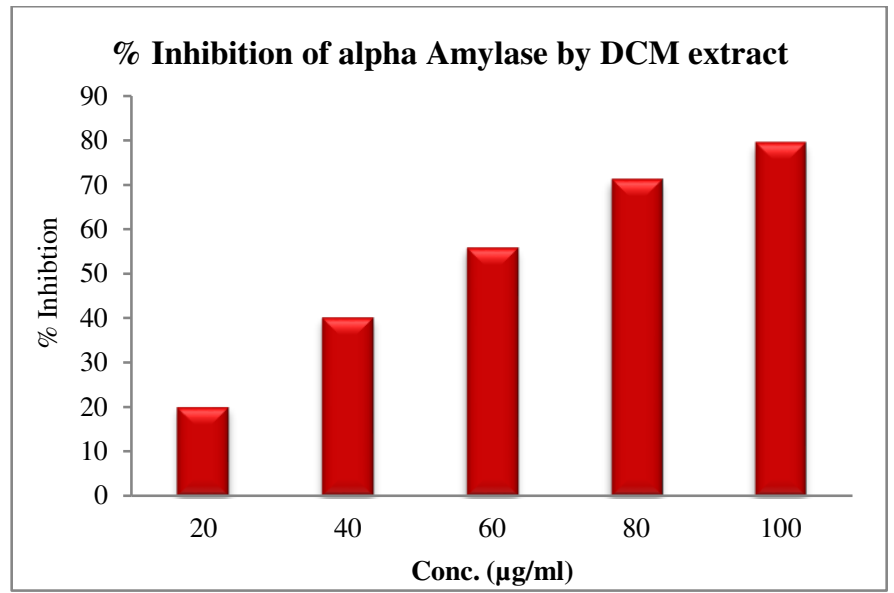

Fig 4: Graph showing inhibition of alpha-amylase by DCM Extract

Table 5: Data of ACAROSE Standard Drug for Glycosidase Enzyme

\begin{tabular}{|c|c|c|c|}
\hline S. No & $\begin{array}{l}\text { Conc. of Sample } \\
(\mu \mathrm{g} / \mathrm{ml})\end{array}$ & $\begin{array}{c}\% \text { of } \\
\text { Inhibition }\end{array}$ & $\mathbf{I C}_{50}$ \\
\hline 1. & 5 & 10.75 & \multirow{10}{*}{25.10} \\
\hline 2 & 10 & 21.32 & \\
\hline 3 & 15 & 33.12 & \\
\hline 4 & 20 & 44.98 & \\
\hline 5 & 25 & 55.73 & \\
\hline 6 & 30 & 67.97 & \\
\hline 7 & 35 & 79.33 & \\
\hline 8 & 40 & 91.45 & \\
\hline 9 & 45 & 104.1 & \\
\hline 10 & 50 & 115.2 & \\
\hline
\end{tabular}

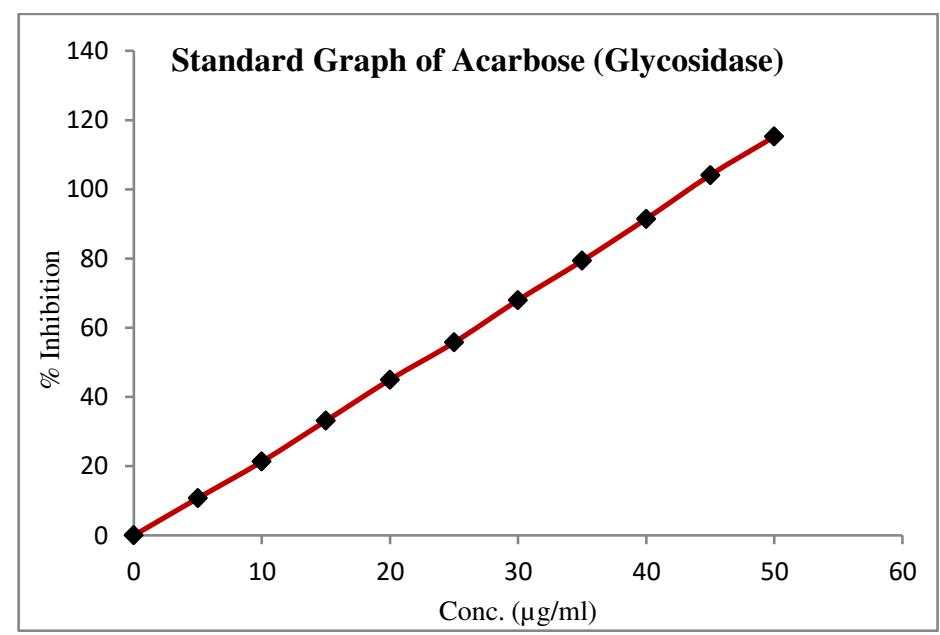

Fig 5: Graph showing inhibition of alpha-glycosidase by ACAROSE Standard Drug 


\begin{tabular}{|c|c|c|c|}
\hline S. No & $\begin{array}{l}\text { Conc. of Sample } \\
(\mu \mathrm{g} / \mathrm{ml})\end{array}$ & $\begin{array}{c}\% \text { of } \\
\text { Inhibition }\end{array}$ & $\mathrm{IC}_{50}$ \\
\hline 1 & 20 & 23.1 & \multirow{5}{*}{51.52} \\
\hline 2 & 40 & 39.2 & \\
\hline 3 & 60 & 56.9 & \\
\hline 4 & 80 & 62.3 & \\
\hline 5 & 100 & 71.5 & \\
\hline
\end{tabular}

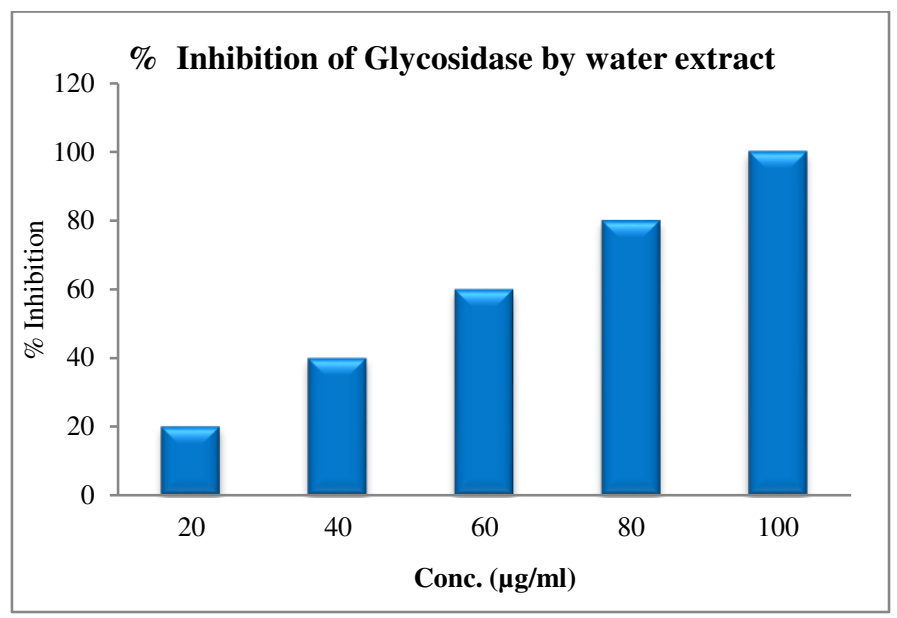

Fig 6: Graph showing inhibition of alpha-glycosidase by water Extract

Table 7: Data of Ethanolic Extract for Glycosidase Enzyme

\begin{tabular}{|c|c|c|c|}
\hline S. No & $\begin{array}{c}\text { Conc. of Sample } \\
(\mu \mathrm{g} / \mathrm{ml})\end{array}$ & $\begin{array}{c}\% \text { of } \\
\text { Inhibition }\end{array}$ & $\mathrm{IC}_{50}$ \\
\hline 1 & 20 & 25.99 & \multirow{5}{*}{51.57} \\
\hline 2 & 40 & 42.58 & \\
\hline 3 & 60 & 59.43 & \\
\hline 4 & 80 & 69.22 & \\
\hline 5 & 100 & 77.56 & \\
\hline
\end{tabular}

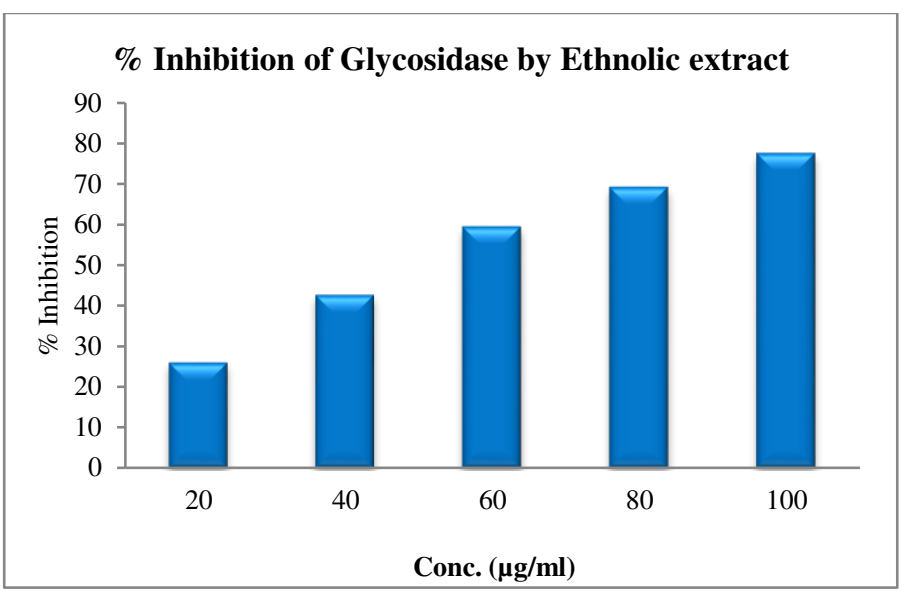

Fig 7: Graph showing inhibition of alpha-glycosidase by Ethanolic Extract

Table 8: Data of DCM Extract for Glycosidase Enzyme

\begin{tabular}{|c|c|c|c|}
\hline S. No & $\begin{array}{l}\text { Conc. of Sample } \\
\quad(\mu \mathrm{g} / \mathrm{ml})\end{array}$ & $\begin{array}{c}\% \text { Of } \\
\text { Inhibition }\end{array}$ & $\mathrm{IC}_{50}$ \\
\hline 1 & 20 & 25.51 & \multirow{5}{*}{56.15} \\
\hline 2 & 40 & 42.52 & \\
\hline 3 & 60 & 57.31 & \\
\hline 4 & 80 & 67.17 & \\
\hline 5 & 100 & 77.13 & \\
\hline
\end{tabular}

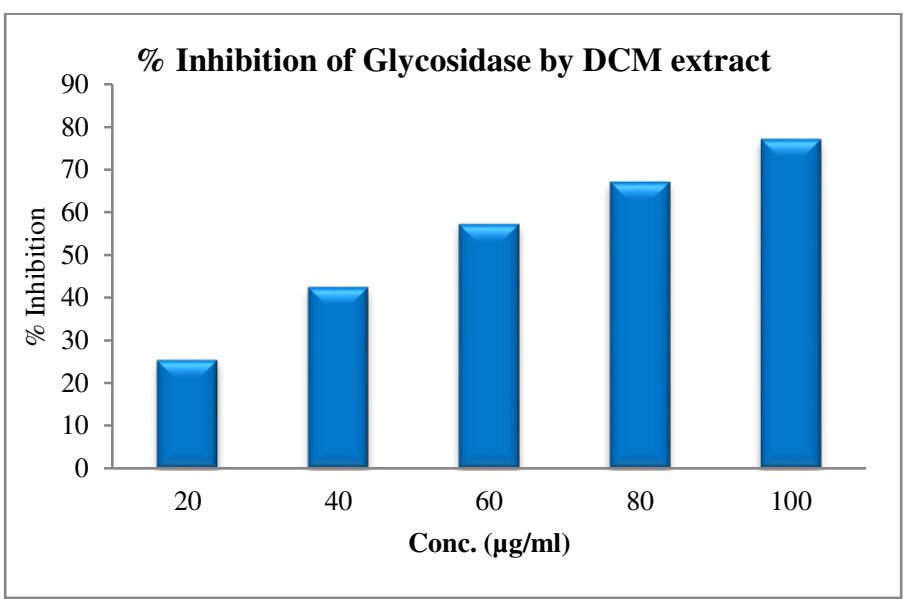

Fig 8: Graph showing inhibition of alpha-glycosidase by DCM Extract 
As per the results obtained from the above study it had been found that the inhibition of amylase and glycosidase are dose-dependent, as there is an increase in percentage inhibition in the enzymes by the increase in the concentration of the plant extracts.

The inhibition percentage of alpha amylase was found to be $54.95 \%$ by water extract, $53.01 \%$ by ethanol extract and $47.87 \%$ by DCM extract, similarly the percentage inhibition of alpha glucosidase was found to be $48.48 \%$ by water extract, $48.48 \%$ by ethanol extract and $43.85 \%$ by DCM extracts. Also as per the comparative study the inhibition of glucosidases enzymes occurs more than the amylases.

The ethanolic extract of the concerned plant when analysed by GC-MS technique the following compounds have been identified.

\section{Compound Name: Methyl 2-furoate}

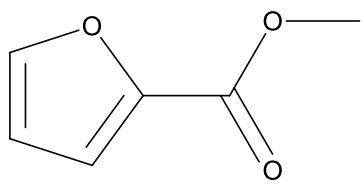

Chemical Formula: $\mathrm{C}_{6} \mathrm{H}_{6} \mathrm{O}_{3}$

Molecular Weight: 126.11

\section{GC-MS}

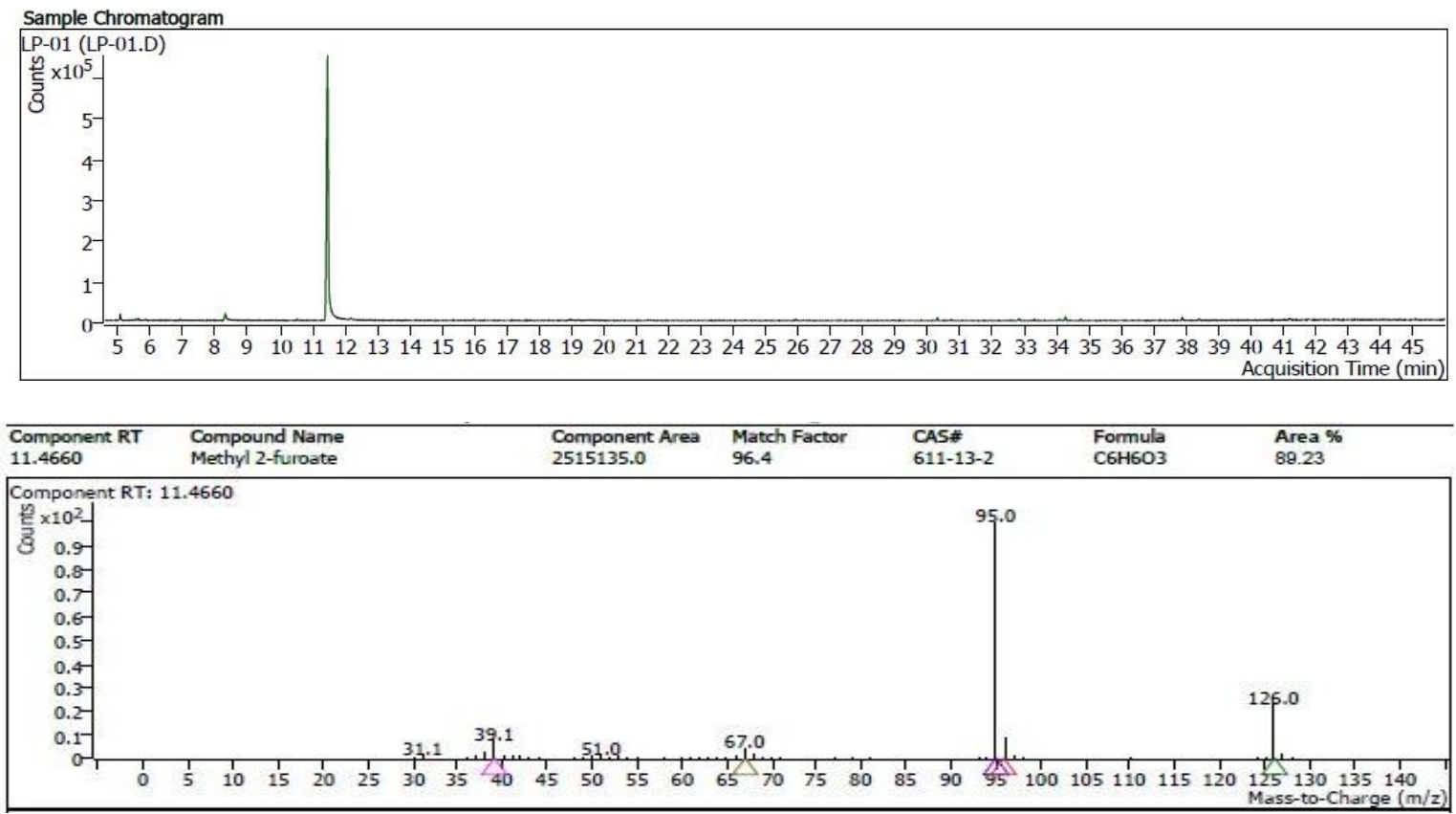


Compound Name: 5-hydroxymethyl furfural

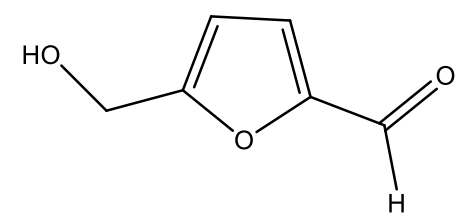

Chemical Formula: $\mathrm{C}_{6} \mathrm{H}_{6} \mathrm{O}_{3}$

Molecular Weight: 126.03

\section{HR-MS}

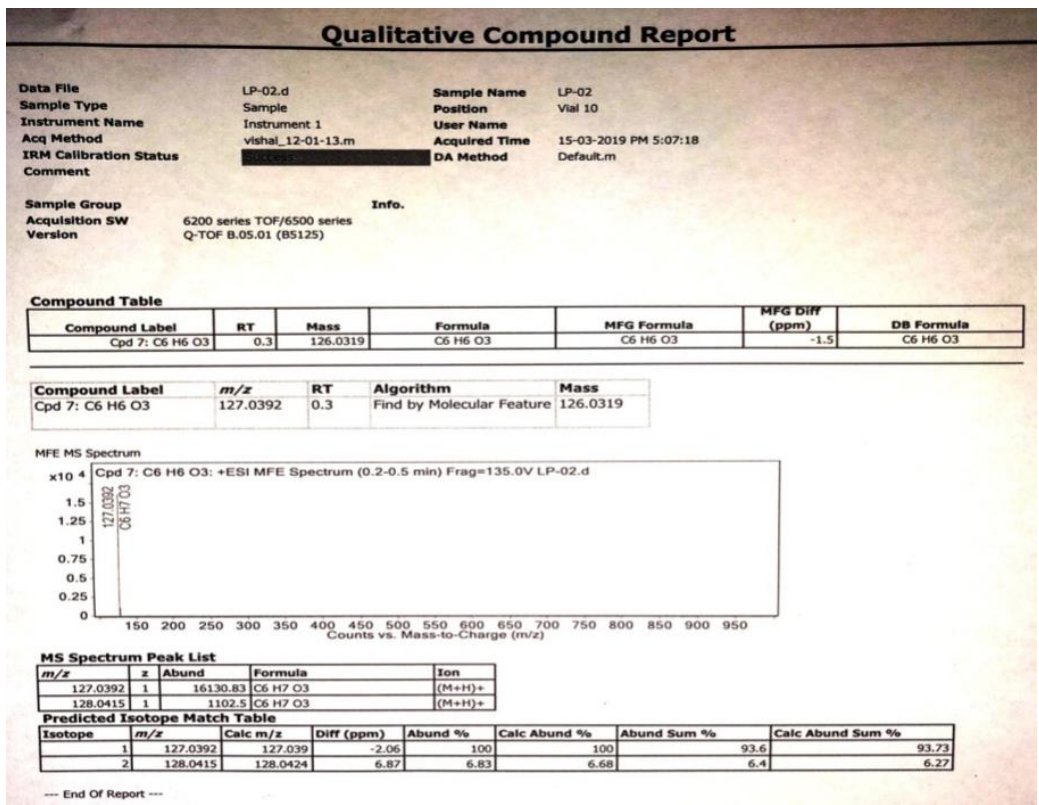

Compound Name: Methyl piperate<smiles>COC(=O)/C=C/C=C/c1ccc2c(c1)OCO2</smiles>

Chemical Formula: $\mathrm{C}_{13} \mathrm{H}_{12} \mathrm{O}_{4}$ Molecular Weight: 232.23

\section{ESIMS}




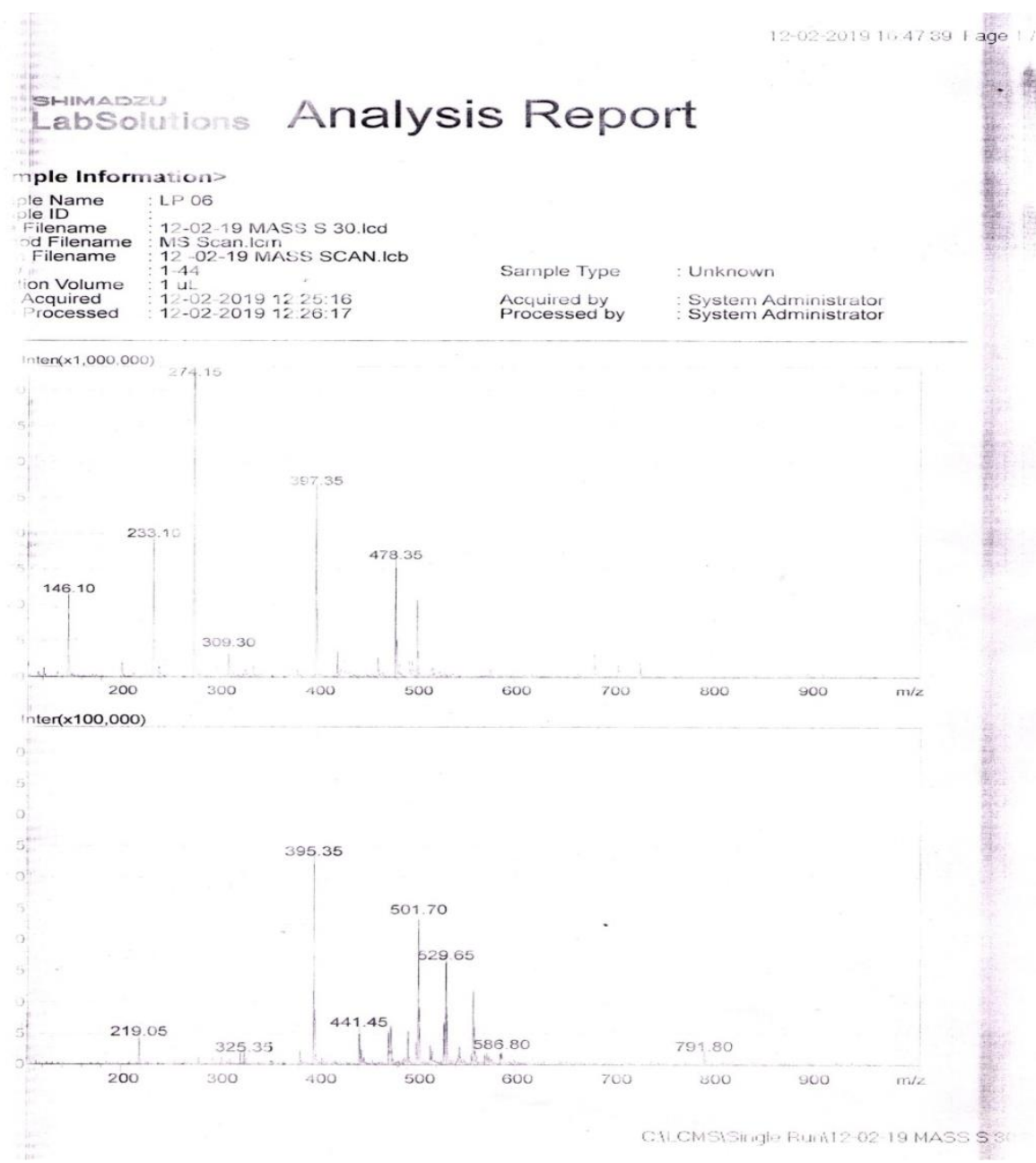

Compound Name: Piperine

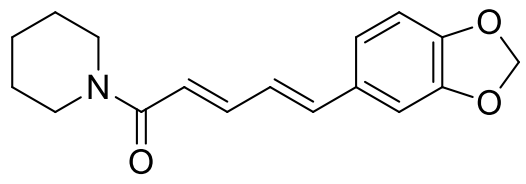

Chemical Formula: $\mathrm{C}_{17} \mathrm{H}_{19} \mathrm{NO}_{3}$

Molecular Weight: 285.34 


\section{ESIMS}

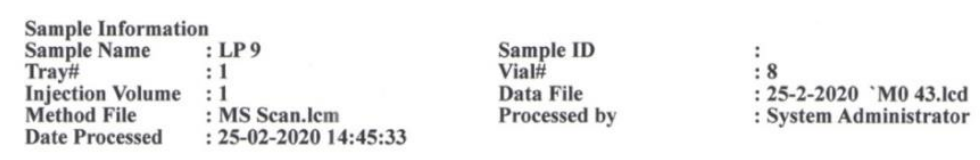

MS Spectrum

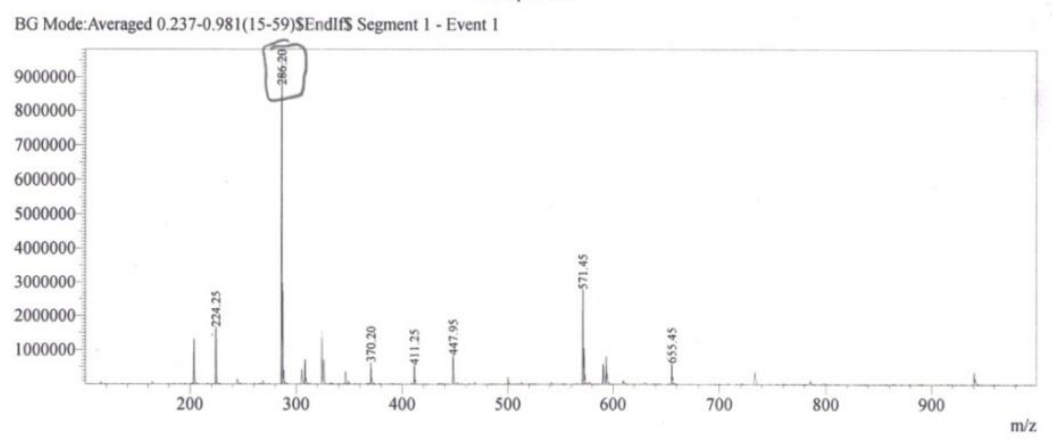

Compound name: 7, 10-Hexadecadienoic acid methyl ester

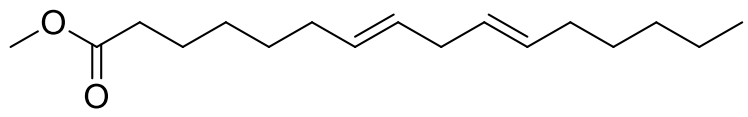

Chemical Formula: $\mathrm{C}_{17} \mathrm{H}_{30} \mathrm{O}_{2}$

Molecular Weight: 266.42

\section{ESIMS}
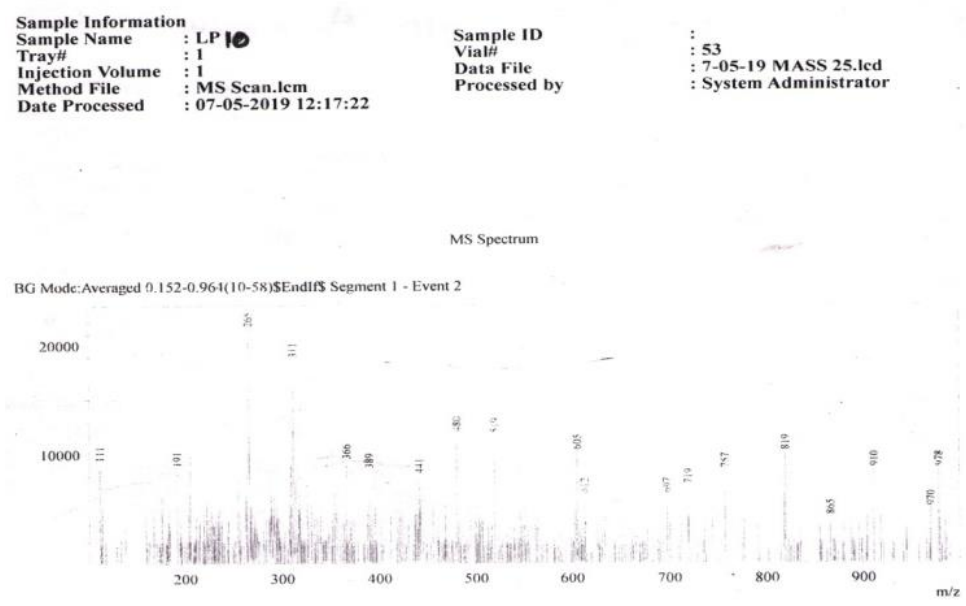

Compound Name: Palmitic acid

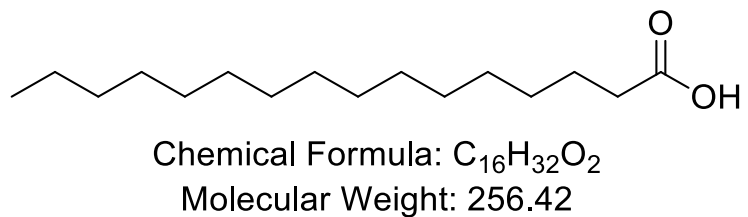

Molecular Weight: 256.42 


\section{GCMS}
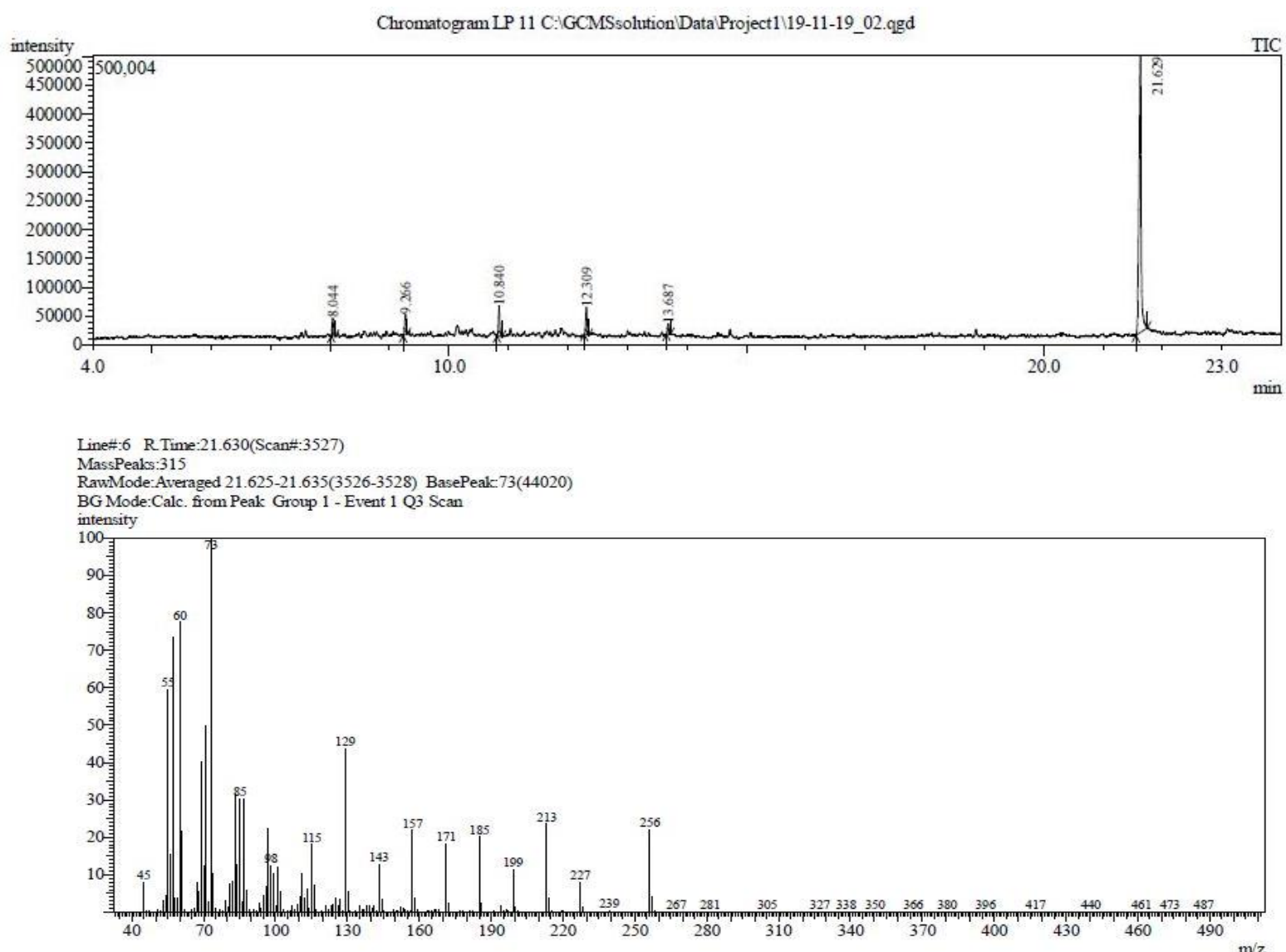

Compound Name: Methyl palmitate<smiles>CCCCCCCCCCCCCCCC(=O)OC</smiles>

Chemical Formula: $\mathrm{C}_{17} \mathrm{H}_{34} \mathrm{O}_{2}$

Molecular Weight: 270.45

\section{GC-MS}

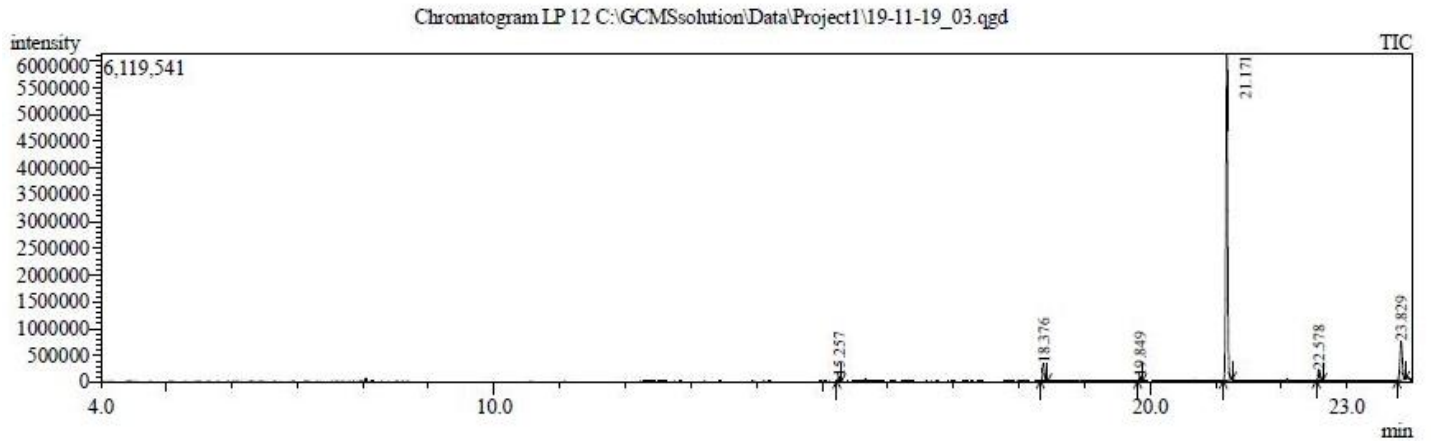




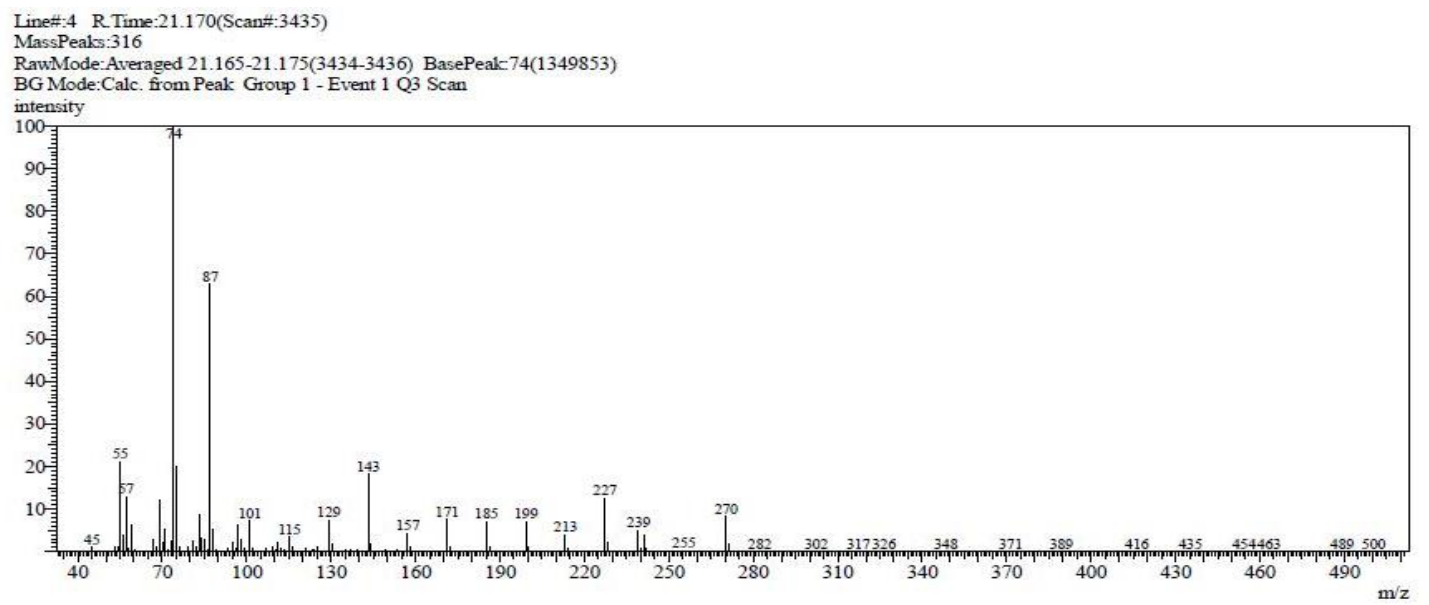

\section{Discussion}

Diabetes mellitus is completely a metabolic disorder and the key factor responsible for it is insulin. The decline of insulin in the body has direct affect on the consumption of carbohydrate, fat and protein metabolism (Rajiv Gandhi, 2012). Presently it seems impossible to control diabetes mellitus without its side effects by allopathic medicines. The present study which is based on the inhibition of alpha-amylase and alpha-glycosidase delays the breakdown of carbohydrate, due to which a decline in the absorption of glucose occurs; as a result of which the inclination in the postprandial blood glucose level reduces (Rhabaso Lhoret, 2014) The inhibitors of Alpha- amylase and glucosidase decrease the digestion of carbohydrates which declines their absorption. Two standard drugs viz Acarbose and miglitol are the well known inhibitors of $\alpha$-glucosidases thereby reduce the absorption of starch and disaccharides (Davis $\mathrm{SN}, 2001)$. So many experiments are being taken into consideration which may reduce the postprandial (PP) blood glucose level in patients with diabetes mellitus to prevent absorption of carbohydrate after food intake. The Postprandial blood glucose level in diabetic patients may reduce by the inhibition of $\alpha$-amylase and $\alpha$-glucosidases (Conforti F, 2005). The inhibitors of $\alpha$ amylase acts as anti-nutrients, obstructs the digestion and absorption of carbohydrates among which Acarbose is a well known inhibitor because being a complex oligosaccharide delays the digestion of carbohydrates, so suppresses the action of pancreatic amylase in the breakdown of starch.

The study in reference evaluates alpha-glucosidase and alpha-amylase inhibition by various extracts of Lilium polyphyllum. The finding reveals that Lilium polyphyllum efficiently inhibits both alpha-amylase and alpha-glucosidase respectively. From the study it had been 
found that the inhibiting potential of various extracts increases correspondingly with the polar nature of the solvents.

The ethanol extracts of the concerned plant were subjected to GC-MS analysis and the compounds which have been isolated help in the justification of the antidiabetic properties of the concerned plant, Methyl 2-furoate (Xu Z, 2008), 5-hydroxymethyl furfural (Lenzen S, 2008), Methyl piperate, Piperine, (Ghosh R, 2004) Palmitic acid (Matsui T, 2001) Methyl Palmitate (Kumar GPS, 2006).

\section{Conclusion}

The study in reference showed that the plant extracts in reference have good inhibiting potential against the amylase and glycosidase enzymes. The inhibiting potential of natural products have been found as a good choice for the diabetic patients as they did not led to side effects. Similarly in the above study it had been found that Lilium polyphyllum posses many biosignitures which have the amylase and glycosidase inhibiting potential, among which polar components have more tendency than the less polar. So the plant in reference with a limited concentration range should be consumed along with the daily routine diet.

\section{Declaration:}

I/We declare that this is an original research work and is not previously published or presented elsewhere in any language and is also not in consideration in any other journal simultaneously.

I and we, all authors of the above manuscript are agree that the content of this manuscript will not be copyrighted, submitted, or published elsewhere (including the internet), and is also not plagiarized from any language according to the policy of the journal.

1. Ethics approval and consent to participate: not applicable

2. Consent to publish: Permission from all the authors

3. Availability of data and materials: Everything was made available from the market, and data analysis from IIIM Jammu.

4. Competing interests: Not applicable

5. Funding: no applicable

6. Authors' Contributions: Material collection and experimental work by Dr. Amin and Dr Ashraf, spectroscopic analysis by Ms. Priya

7. Acknowledgements: we would like to acknowledge IIIM Jammu and PMU university Saudi Arabia for allowing us to carry out the work. 


\section{References}

1. Pandeya G, Sashtri K, Charaka Samhita. 2011.(part I) (Sanskrit-Hindi) Chaukhambha Bharatee Academy, Varanasi, India. pp: 587.

2. Sharma I, Singh A. Clinical Studies with Ayurvedic Formulations-A Practitioner's Preview. J Nat Ayurvedic Med. 2017; 1(1): 1-5.

3. Subramoniam A, Madhavachandran V, Gangaprasad A. Medicinal plants in the treatment of arthritis. Annals of Phytomedicine 2013; 2(1):3-36.

4. Ayurvedic Pharmacopoeia of India. 2001. Ministry of Health and Family Welfare Department of Indian System of Medicine and Homeopathy, Vol.5, New Delhi; 103.

5. Dhyani A, Bahuguna YM, Semwal DP, Nautiyal BP, Nautiyal MC. Anatomical features of Lilium polyphyllum D. Don ex Royle (Liliaceae). Journal of American science, 2009; 5(5): 85-90.

6. Dhyani A. Lilium polyphyllum-rarest of rare lilies. Reasearch gate. 2010; 85-91.

7. Kumari S. Pharmacognostical \& Phytochemical studies of Roscea precera (Kakoi) and lilium polyphyllum (Ksheerkakoli) in comparison with market samples. Pharmacognosy Journal. 2011; 3(25):32-38.

8. Chang C, Chen C T, Tsai YC and Chang WC. A tissue culture protocol for propagation of a rare plant, Lilium speciosum Thunb. var. glorisoides Baker. Bot. Bull. Acad. Sin. 2000; 41: 139-142

9. Wawrosch C, Malla PR and Kopp B. Clonal propagation of Lilium nepalense D.Don, a threatened medicinal plant of Nepal. Plant Cell Reproduction. 2001; 20: 285-288.

10. Sharma BD and Balkrishna AV. Vitality strengthening Astavarga Plants (Jeevaniya \& Vayasthapan Paudhe). Divya Publishers, Divya Yog Mandir, Haridwar, Uttaranchal. 2005.

11. Das AK, Rai. A world without diabetes and its complications: A preventive program. In: Jayaram BM (Ed.), Type 2 Diabetes and its complications (A preventive program. Microlabe limited: Bangalore, 2008: 1-2.

12. Gupta R, Misra A. Type 2 diabetes in India: regional disparities. British Journal of Diabetes and Vascular Disease 2007; 7:12-16.

13. Abate N, Chandalia M. Ethnicity, type 2 diabetes \& migrant Asian Indians. Indian Journal of Medical Research 2007; 125:251-258. 
14. Hamdan, Afifi FU. Studies on the in vitro and in vivo hypoglycemic activities of some medicinal plants used in treatment of diabetes in Jordanian traditional medicine. Journal of Ethnopharmacology. 2004; 93:117-121.

15. Thalapaneni NR, Chidambaram KA, Ellappan T, Sabapati ML, Mandal SC. "Inhibition of carbohydrate digestive enzymes by Talinum portulacifolium (Forssk) leaf extract". Journal of Complementary and Integrative Medicine. 2008; 5(1): 1-10.

16. Heidari R, Zareae S, Heidarizadeh M. "Extraction, Purification, and Inhibitory Effect of Alpha-Amylase Inhibitor from Wheat (Triticum aestivum Var. Zarrin)". Pakistan Journal of Nutrition. 2005; 4 (2): 101-105.

17. Krishnaveni, S, B. Theymoli, and Sadasivam, S. "Phenol Sulphuric Acid method". Food Chem. 1984; 15: 229.

18. Shai, L. J, P. Masoko, M. PMokgotho. Yeast alpha glucosidase inhibitory and antioxidant activities of six medicinal plants collected in Phalaborwa, South Africa. South African J. Bot. 2010; 76: 465470.

19. Rajiv Gandhi, G. Sasikumar, P. Antidiabetic effect of Merremia emarginata Burm.F. in Streptozotocin induced diabetic rats. Asian. Paci. J. Tropi. Biomedicine. 2012; 2: 281286.

20. Rhabaso Lhoret, R., and Chiasson J.L. 2004. Glucosidase inhibitors. In: Defronzo R.A, Ferrannini E, Keen H, Zimmet P. (Eds.), International Textbook of Diabetes Mellitus, Vol. 1, third ed. John Wiley and Sons Ltd., UK.; 901-914.

21. Davis SN, Granner DK. Insulin, oral hypoglycemic agents and the pharmacology of endocrine pancreas. In: Brunton LL, Lazo JS, Parker KL (Ed.), Goodman and Gilman's: The pharmacological basis of therapeutics, 11th ed. (McGraw-Hill Medical Publication Division: New York. 2001; 1706-1707.

22. Conforti F, Statti G, Loizzo MR, Sacchetti G, Poli F, Menichini F. Traditional Medicinal Herbs and Food Plants Have the Potential to Inhibit Key Carbohydrate Hydrolyzing Enzymes In Vitro and Reduce Postprandial Blood Glucose Peaks In Vivo. Biological \& Pharmaceutical Bulletin. 2005; 28 (6): 1098-1102.

23. Xu Z, Wang X, Zhou M, Ma L, Deng Y, Zhang H, Zhao A, Zhang Y, Jia W. The antidiabtic activity of total lignan from Fructus arctii against alloxan-induced diabetes in mice and rats. Phytother Res. 2008; 22; 97-101.

24. Lenzen S. The mechanisms of alloxan- and streptozotocininduced diabetes. Diabetologia, 2008; 51: 216-226. 
25. Ghosh R, Sharatchandra Kh, Rita S, Thokchom IS. Hypoglycemic activity of Ficus hispida (bark) in normal and diabetic albino rats. Indian J Pharmacol. 2004; 36: 222-225.

26. Matsui T, Ueda T, Oki T, Sugita K, Terahara N, Matsumoto K. $\alpha$-Glucosidase inhibitory action of natural acylated anthocyanins. J Agric Food Chem. 2001; 49, 1948-1951.

27. Kumar GPS, Arulselvan P, Kumar DS, Subramanian P. Antidiabetic activity of fruits of Terminalia chebula on streptozotocin induced diabetic rats. J Health Science. 2006; 52(3): 283-291. 
Figures

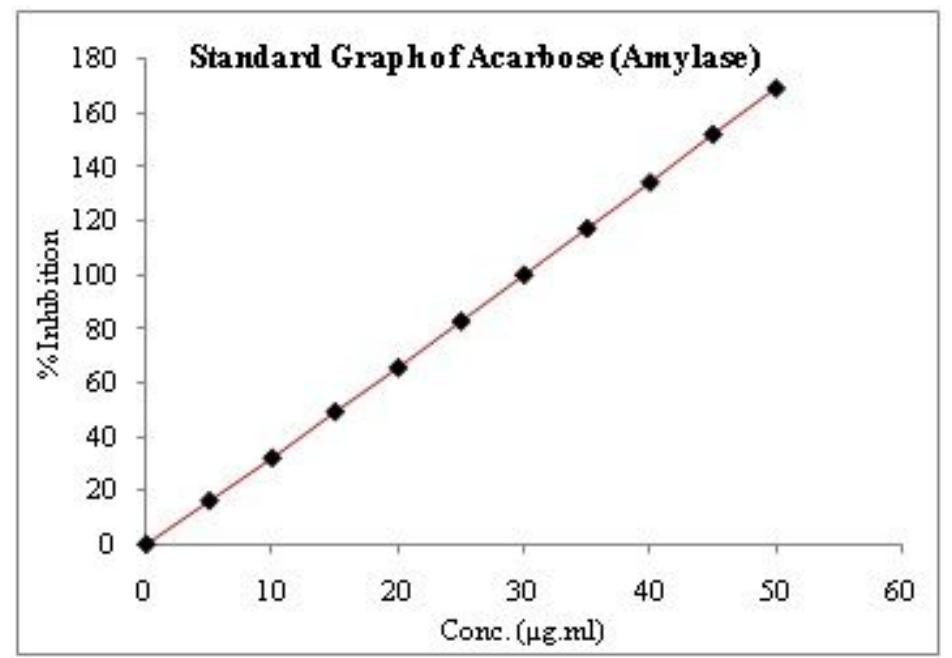

\section{Figure 1}

Graph showing inhibition of alpha-amylase by ACAROSE Standard Drug

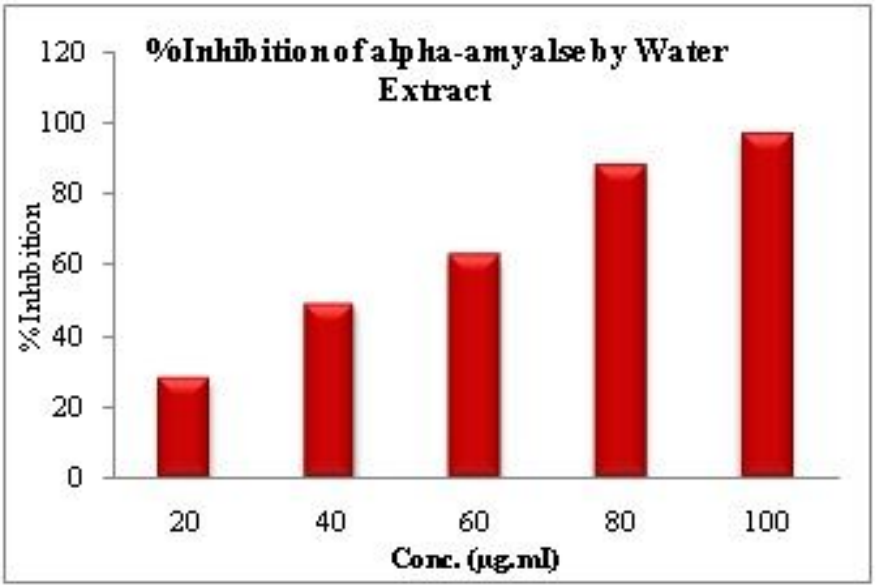

Figure 2

Graph showing inhibition of alpha-amylase by Water Extract

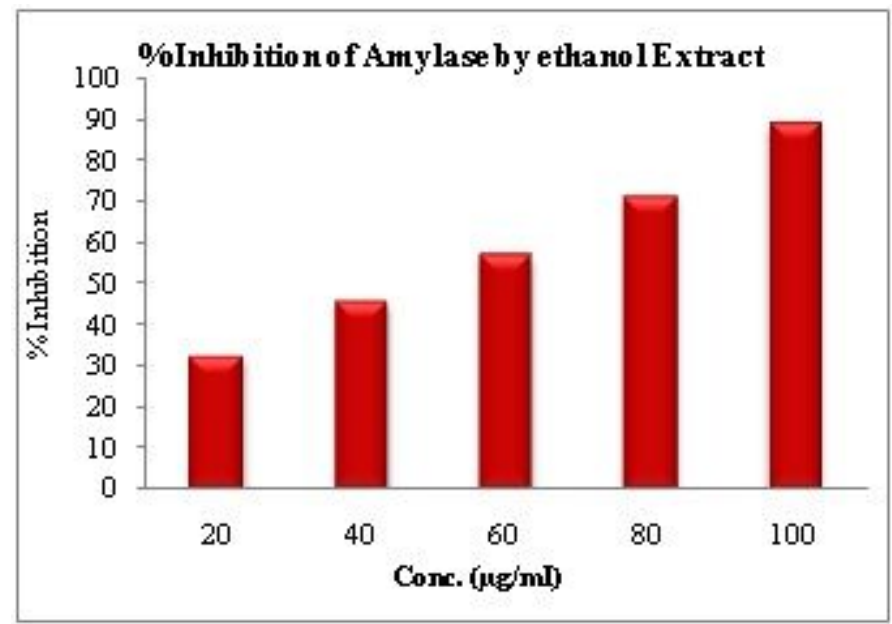


Figure 3

Graph showing inhibition of alpha-amylase by Ethanolic Extract

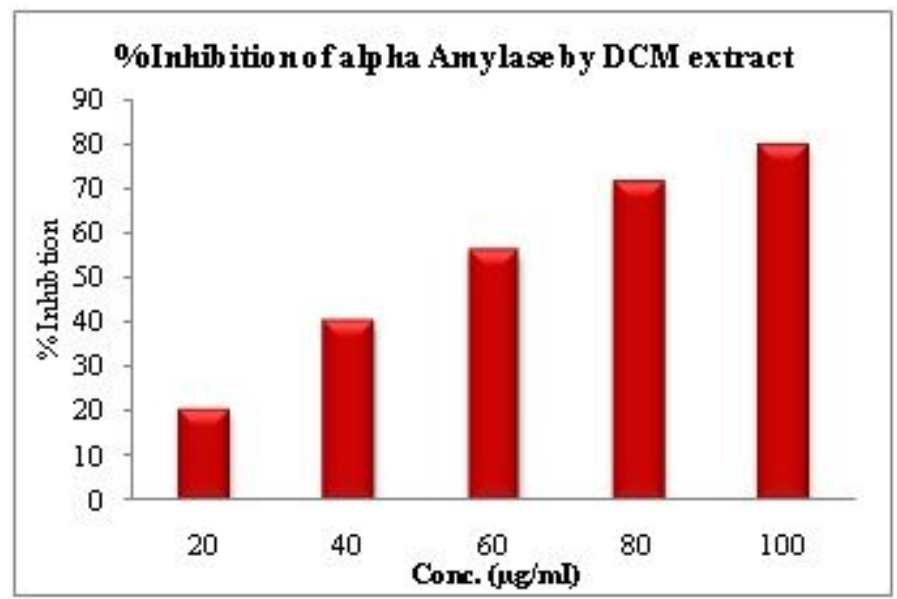

\section{Figure 4}

Graph showing inhibition of alpha-amylase by DCM Extract

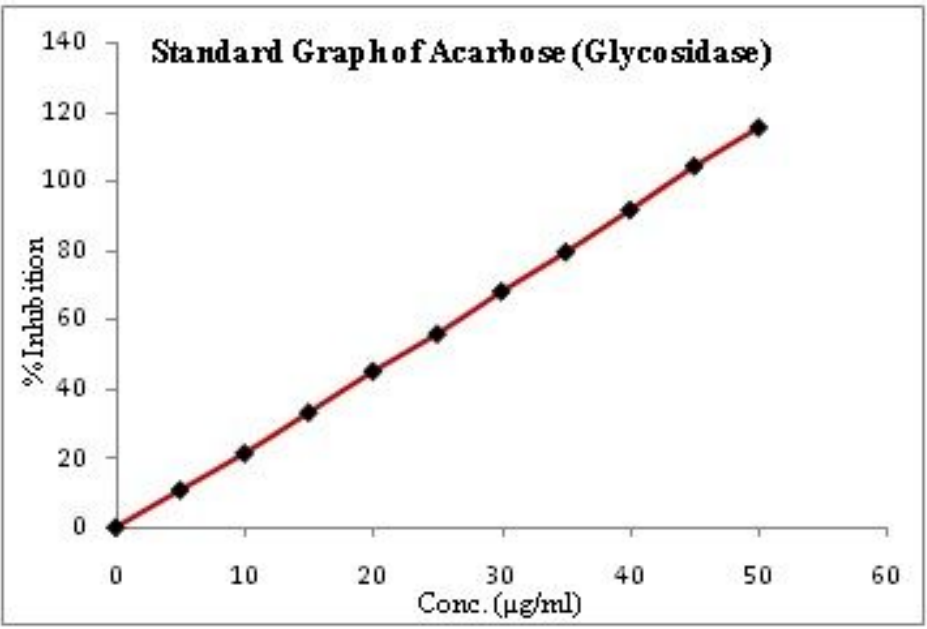

Figure 5

Graph showing inhibition of alpha-glycosidase by ACAROSE Standard Drug

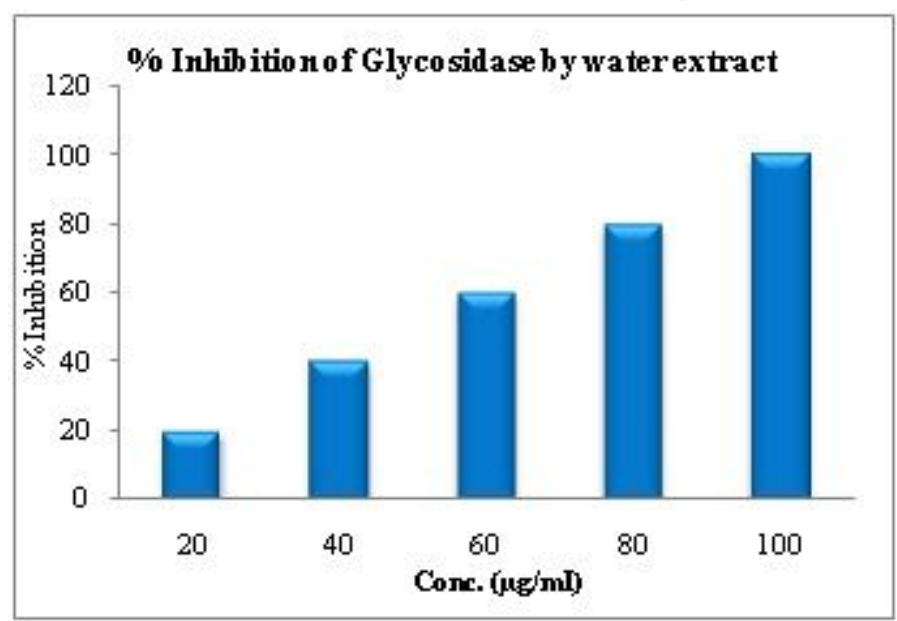


Figure 6

Graph showing inhibition of alpha-glycosidase by water Extract

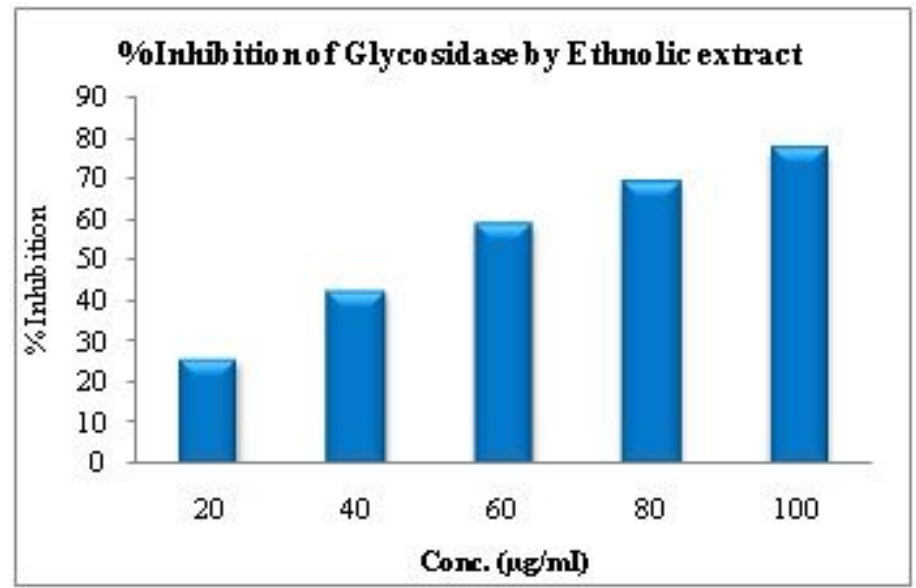

\section{Figure 7}

Graph showing inhibition of alpha-glycosidase by Ethanolic Extract

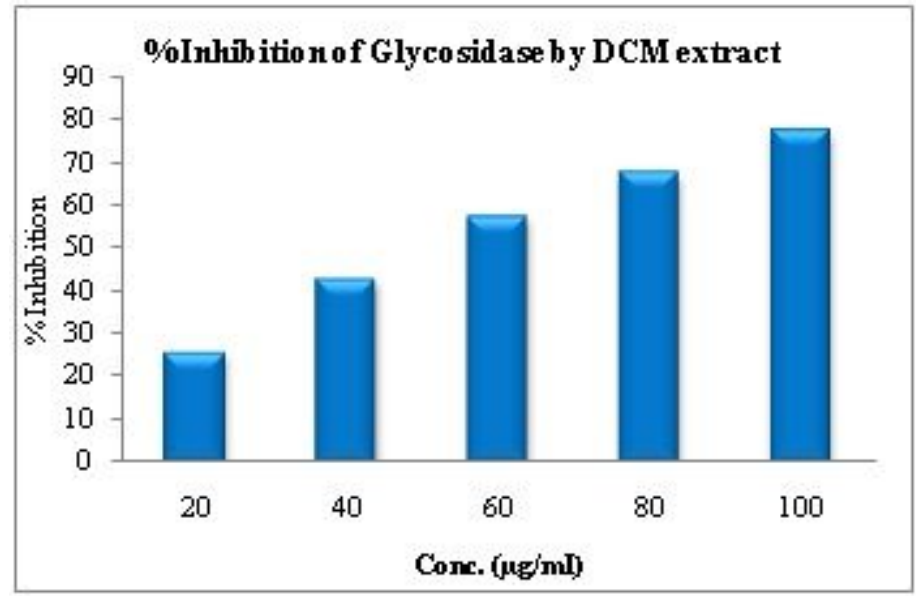

\section{Figure 8}

Graph showing inhibition of alpha-glycosidase by DCM Extract 